Article

\title{
Agroecology as a Practice-Based Tool for Peacebuilding in Fragile Environments? Three Stories from Rural Zimbabwe
}

\author{
Georgina McAllister * and Julia Wright \\ Centre for Agroecology, Water and Resilience, Coventry University, Coventry CV1 5FB, UK; \\ aa9469@coventry.ac.uk \\ * Correspondence: mcallisg@uni.coventry.ac.uk
}

Received: 10 December 2018; Accepted: 27 January 2019; Published: 2 February 2019

check for updates

\begin{abstract}
This paper investigates how transformative agroecology may contribute to the critical reframing of social-ecological relationships, and how this might in turn create a foundation for bottom-up peace formation in fragile environments, within which rural communities are often habituated to conditions of control, violence and mistrust that drive social division. Here, we consider the value of social farming in reforging relationships through which social-ecological change may be negotiated and alternative sources of agency and identity may be cultivated in order to transcend entrenched patterns of division. Three case studies are presented, drawing on primary data from participatory action research with farming communities in Zimbabwe that also consider the differential attitudes and experiences of agroecological and conventional farmers. The study finds that, where agroecological farmers were exposed to more plural ways of thinking, being and acting together, levels of autonomy from coercive structures were increasing, as were both a sense of efficacy and optimism to effect social-ecological change. This was particularly pronounced where collective processes to shape physical landscapes were forging bonds of solidarity, reciprocity and trust. In these cases, agroecological farmers were increasingly able to envisage a future together shaped by collective endeavour, evidenced by changing attitudes and relationships with one another and their environment. The paper explores the extent to which farmers in each location were able to instrumentalise resilience and agency for everyday peace, and the variances found according to historical context and local power dynamics that represent barriers to change.
\end{abstract}

Keywords: agroecology; agency; knowledge; peacebuilding; social capital; transformation; Zimbabwe

\section{Introduction}

This paper investigates the transformative potential of agroecology located in fragile post-colonial environments, where nation-building was often born out of violence and social upheaval. Here, the victors of an unstable and ultimately negative peace have manufactured consent through coercive social, economic and/or political strategies. These strategies suppress pluralism, which is seen as antithetical to the singular vision of nation, growth and development. What emerges from such periods of control and division reaches into every aspect of social life, forming complex layers of popular resistance, compliance, apathy, activism and nostalgia. This is an environment where 'tyrannical regimes frequently manipulated populations by creating isolation, separating people from each other, crushing their capacity for critical thinking, and reducing their power to resist' [1] (p. 3).

In these fragile states, small-scale farming continues to be the mainstay of rural livelihoods [2]. Yet agriculture itself receives scant attention either in peacebuilding strategies or literature. Where peace and environmental concerns do coalesce, they tend to centre on arguments around the causes of 
conflict, such as greed versus grievance or scarcity versus abundance [3] and on the governance of transnational resources, such as watershed and dams [4-6]; or wildlife 'peace parks' [7-9]. This has a tendency to result in overarchingly technocratic prescriptions that focus on matters of security and/or on high-level governance mechanisms, and downplay or disregard the structural realities of land enclosure and the needs of resource users such as farmers. As such, much of this literature fails to engage with the underlying power and complex social relations that define access to, and control over, environmental resources. This study, therefore, engages with the view of the environment as an arena within which conflicts and claims over property, assets, labour, and the politics of recognition play out at the local community level. From this perspective, 'violent environments' are less about struggles over natural resources per se, but rather the structural ways in which these resources are politicised and transformed into entitlements as a result of the ebb and flow of shifting alliances between powerholders [10]. As such, violent environments are described as 'site-specific phenomena rooted in local histories and societies, yet connected to larger processes of material transformation and power relations.' [11] (p. 25).

In bringing together agroecology and peacebuilding for the first time, this paper draws on the experiences of farming communities of agroecological practice in rural Zimbabwe. Here, a history of land struggles and agrarian change, combined with its colonial legacy of violence, governmental control and centralised land-use planning - peopled by a cadre of technical experts, or technocrats—continues to shape social-ecological relationships. Moreover, just as dramatic agrarian change increased opportunities for some, so growing class differentiation sowed the seeds of dissent and nationalism, driving irrevocably towards liberation. The violence that this unleashed laid bare the layers of social struggles taking place, marked by power positioning, consolidation and violence [12-14]. These layers continue to shape the socio-political landscape, and divide communities. The post-independence polity that emerged is driven by a strong centralising party-state increasingly reinforced by an authoritarian populism that has proven deeply intolerant of pluralism [15]. In rural Zimbabwe, violence remains ever-present in its structural form. This is exemplified by the withholding of diminishing patronage resources, such as land and welfare entitlements, on the basis of ethnicity, party, church or family affiliation. Furthermore, this atmosphere of negative peace has been punctuated by periods of direct violence perpetrated by the state, either by the security services or through its patronage networks to enforce compliance, particularly during elections.

More recently, as agrarian change has again accelerated under land reform, particularly since 2000, normative constructions of land-use and farming are once again at the centre of the debate about agricultural modernisation and, with it, questions about the viability of smallholder agriculture. These tensions continue to be 'reflected in the struggles over land and patronage-based allocation of resources' [16].

Positive peace, which sits beyond the absence of violent conflict, may be found in the restoration of relationships; the creation of social systems that serve the needs of all; and the constructive resolution of conflicts that give rise to change [17]. To understand how this might take place in the context of the everyday, often hidden from view in the rural margins, we present data to explore how agroecological activities are reforging relationships to negotiate social-ecological change. Here, we consider the contextual significance of agroecological practices for improved resilience during times of stress and crises. We then go on to explore the extent to which these localised activities are re-forging social-ecological relationships rooted in collective action in ways that not only enhance resilience, but hold the potential to transform habituated conditions that perpetuate social division. The findings between study sites vary considerably, with lower levels of resilience and peace experienced where agency was more constrained, and efforts to foster it through practice had gone unexplored. These findings lead to a discussion on the role of agency for resilience-building and thinking, the way in which relationships can be transformed through collective landscape endeavours, and the implications for peace building. 


\section{Research Issue: Agroecology, Peacebuilding and Changing Social-Ecological Relationships in Zimbabwe}

\subsection{Agroecology and Peacebuilding}

Given its socio-cultural foundations, agroecology includes any ecologically sensitive 'place-based agricultures' rooted in cultural heritage, and consists of a wide range of systems and designs which maintain functional on-farm biodiversity and support resilient agroecosystems [18-20]. What links all of these is that each is highly contextual in its recognition of socio-ecological complexity 'promoting continuous adaptation to build resilient systems' [21] (p. 76). Grounded by place and culture, social farming refers to systems that are knowledge and labour intensive, and both draw upon and promote social capital. This is defined here as relations of trust; reciprocity and exchange; common rules, norms and sanctions; and connectedness between networks and groups [22]. Researcher-practitioner interaction in the form of participatory action research has provided the foundation of agroecological praxis, cataloguing pre-existing knowledge and social farming practices based on complex social-ecological interactions [23]. One prospectus at the heart of agroecology is the repositioning of farmer-practitioners as citizen scientists and experts capable of identifying and overcoming obstacles in order to optimise agrobiodiversity for both ecosystem and socio-cultural functions. In this way, transformative agroecology represents a synthesis between existing knowledge and research (local and formal) in an iterative process which views socio-cultural practices, and ecological and political processes, as intrinsically linked.

Conventional or industrial agriculture, on the other hand, is characterised by homogenous landscapes, a narrow range of biodiversity, knowledge and complexity, and top-down technological prescriptions. In this sense, conventional systems do little to nurture resilience, construct a positive vision of a collective future, or foster facets of critical agency. Rather, they may lead to competitive, zero-sum relations that drive social injustice and ecological unsustainability [24-26]. For this reason, we would argue that conventional approaches, in particular their typical socio-political dimensions, are counterproductive to transformative peacebuilding.

Central to this mode of enquiry is the value of knowledge and experience as a vehicle for transformation towards a more socially just and equitable future. Acting in concert within and upon one's own environment builds confidence in shaping change as continuous interaction, forming new habits and capacities, through which self-organisation from below, within otherwise fixed and deterministic rules of social-ecological interaction, may emerge. Furthermore, in doing so, this process is capable of expanding the range of available futures as seen from multiple standpoints [27]. This is described by Olsson et al. as 'a collective learning process that builds experience with ecosystem change that evolves as a part of the social memory, and embeds practices that nurture ecological memory' [28] (p. 77).

In investigating the value of agroecology in application to human-centred peacebuilding, as with nonviolence, it is proposed here that agroecological practice provides a situated, discursive learning ground which 'prepares disempowered and oppressed groups for constructive conflict engagement.' [29] (p. 47). This is because, rather than concentrating exclusively on the substance of a dispute, transformation requires the development of creative change processes that address less visible aspects of relationships [30] that inform the broader social-ecological context.

Learning to pool skills and perform collectively builds further capacity and impetus for ongoing action. As communities of practice capable of transcending conflict boundaries develop [31], so a form of contextual legitimacy for bottom-up peace formation may emerge [32]. In this regard, perceptions of efficacy enable adaptation to change, through which human agency results in a belief in being not only producers of experience but shapers of events [33]. Collective efficacy formed around shared beliefs and the desire for change is therefore an important entry point for developing human agency and, with it, alternative sources of collective power and identity. 
The development of 'efficacy beliefs influence whether people think erratically or strategically, optimistically or pessimistically' affecting our ability to identify goals and appropriate actions, our perseverance in the face of adversity, and the outcomes which are achieved ... 'Unless people believe that they can produce desired effects and forestall undesired ones by their actions, they have little incentive to act' [33] (p. 75). Times of stress or shock are instructive because they represent important triggers for change, heralding periods of questioning and renewal, within which the equilibrium may be so undermined as to present opportunities for transformation. In this way, be they sudden or gradual, such disruptions can 'provide insights into politics and society because they reveal systemic inequities and power relationships, not only in the ways vulnerability to hazard and risk are produced, but in the ways communities, classes and groups organize' [34] (p. 114). These transformations may equally occur in niches at a local level, often in response to deep-seated societal contradiction from which emerges wider social change [35].

Grounded in the restoration of local knowledge, and blended with more plural knowledge sources through dynamic processes of exploration and exchange, a sense of efficacy may emerge with a confidence to embrace social-ecological complexity. As these networks mature, fluid processes emerge without fully knowing where they might lead, as a form of 'bottom-up culturing of reflexive social action' that expresses plurality and tests the boundaries of rigid and often coercive structures [36,37].

These theories are put to the test here by examining the data from three rural communities in Zimbabwe, and the extent to which the re-forging of social-ecological relationships was resulting in changing social attitudes and relations. However, it is first necessary to provide some context on the environment in which these rural communities found themselves.

\subsection{Authoritarianism and Technocratic Developmentalism in Zimbabwe}

Despite the highly differentiated agroecosystems and related farming systems in Zimbabwe, interventionist technical strategies have long 'assumed the superiority of western culture and science' and African smallholder farming as essentially primitive [38] (p. 24). Interspersed with periods of rationalisation and forced prolitarianisation, a history of ill-conceived and poorly-implemented development policies has served to exacerbate natural resource degradation and increase exposure to, and the severity of natural hazards [39-42]. While these policies were resisted on the basis of a more complex understanding of social-ecological interactions and, with it, the benefits of maintaining a more diverse ecosystem, these changes were considered to have undermined the 'capacity of rural people to work collectively' to manage important resources within their agroecosystem [42] (p. 291). Nonetheless, this legacy of a modernising and developmentalist agenda has continued, driven by a strong centralising state that has consistently failed to consider social-ecological relations as complex dynamic systems moderated by social norms and practices. Ultimately, the 'liberation initiatives have found it very difficult to "unthink" the epistemologies created by others' [43] (p. xx).

This legacy can be seen in the Department of Agricultural, Technical and Extension Services (Agritex) that provides technical support for smallholders through the promotion of standard input packages of hybrid maize and nitrogen-based fertilisers as the centrepiece of its 'technology transfer'. Technical training of extension officers often leaves them woefully ill-equipped to the realities of their rural postings, to which the response is more often to convert farmers in return for inputs. Nonetheless, uptake is mixed due, in part, to inconsistent access to inputs $[16,44]$. Periodic attempts to increase popular participation in natural resource management have been short-lived, hampered both by the habituated attitudes and behaviours of technocrats who either did not fully comprehend the process of co-development, and by a mutual mistrust of traditional leaders [45].

For state institutions and traditional leaders, the focus of resource management remains on enforcement, pointing to a strong control orientation embedded in layers of power and social control. Indeed many competing local interests, layered between those of the state and international capital, can be found in the complex narratives and artful negotiations that are creatively fused and adapted 
in defense of livelihood, culture and environment [46], and which define the rules over which social-ecological relations are closely bound and defended.

\subsection{A Context of Politicised Livelihoods and Contested Entitlements}

The political ecology of violence that surrounds entitlements, through the control over access to, and distribution of, natural resources, farming subsidies and welfare entitlements, remains a powerful driver of diverse national and local struggles for power, and is mediated through local patronage networks in the search of legitimacy, consent and control. Farming subsidies have long targeted those considered politically important to the ruling Zimbabwe African National Union-Patriotic Front (ZANU-PF) [47]. Patronage patterns are also associated with food and farming entitlements from the Department of Social Welfare, distributed through ZANU-PF ward councilors and village development committees headed by traditional leaders. Reports include partisan distribution during party meetings, with recipients required to be card-carrying party members [48,49], and the increasing involvement of military and intelligence services in subsidy and food distribution [16,50].

For Gramsci, what this produce is a 'cultural dynamic by which a group claims and sustains a leading position in social life', that is 'culturally exalted' by others [51] (p. 38), and through which patronage benefits are conferred upon some at the expense of others. For Azar, this inability or unwillingness to provide for basic human needs adds to the ongoing sense of disarticulation between the state and society, and creates a source of violence between different identity groups [52]. Under these conditions, nodes of insecurity proliferate, fueling ever-more asymmetric power relations and competition over resource entitlements, and intra-communal tensions in an atmosphere already permeated with mistrust and pervasive security. As elsewhere, the legitimacy of those with customary responsibilities that define land-use and labour sharing has been undermined by co-option, corruption and social division, and trust in their interconnected knowledge ecosystem eroded [1,53,54].

\subsection{Agroecology and Social Farming in Zimbabwe}

In Zimbabwe, social-ecological relations to the land are grounded in traditional beliefs and cultural practices that moderate resource-use through rules, relationships and norms, within which peoples' identities, cosmology, and knowledge are embedded [55]. These revolve around the indivisibility of the tripartite relationship between people, nature and the spirit world inhabited by the ancestors [56]. Rituals are closely bound to farming seasons, defining peoples' obligations and relationships with the surrounding landscape. For adherents, to damage one's ecology is to undermine human existence. According to one African proverb, "Our world is like a drum; strike any part and the vibration is felt all over" [57] (p. 408). In its way of knowing, being and meaning-making for knowledge production, African religion is considered to enhance and generate self-confidence, providing a source of dynamism and creativity. For Tarusarira [57], it also has the capacity to increase one's ability to resist exploitation and domination. This way of life has long-been under attack from the 'civilising' forces of modernity and Christianity - associated with notions of progress, and so often elided with visions of nation and nationalism. Drinkwater describes this, alongside the resulting technocracy, as the 'colonisation of the lifeworld of the Africa people in Zimbabwe' that has led to the marginalisation of traditional religion and its adherents [58] (p. 107).

Many rural people, sometimes reluctantly, still observe chisi or the chief's day, a traditional day of rest for the soil as a mark of respect for the ancestors that reside there. Open pollinated and drought-tolerant small grains may still be collected before being taken to the shrine to soak in the waters to ask the ancestors for rains, good harvests or protection against extreme weather. Yet many more have lost their connections to their knowledge and traditions, reinvented them around new structures, or renounced them in favour of monotheism and/or capitalism. In rural communities across Zimbabwe today, where these rituals and relationships persist in varying degrees, they do so syncretically with Christianity. 
The cultural dimensions of social farming in Zimbabwe incorporate traditions of reciprocity such as collectively organised and shared labour, known as nhimbe or humwe in Shona dialects, or ilima in Ndebele. These practices emerged as a consequence of the shift to an extensive, plough-based agriculture that resulted in the expansion of settlements, with more labour-intensive farming requiring shared labour in the form of reciprocal work groups for clearing, planting, weeding and harvesting [59]. Groups would be formed to rotate around each other's land, in return for which the host family would provide food and refreshments, either a non-alcoholic maize drink called maheu, or beer fermented from maize or sorghum. Involving song and storytelling going in to the evening, ilima or nhimbe would traditionally have been an occasion connecting people through the exchange of information as well as seed. These practices, however, have been disrupted by periods of violence and social upheaval.

During the liberation struggle in the 1960-1970s, communities were forcibly 'villagised' under the guise of protecting them from militia activity, and public meetings were banned under the Rhodesian Law and Order Public Maintenance Act, which included suspicion of farmers collecting together for ilima or nhimbe as being subversive. After independence, this was extended and applied more aggressively in Matabeleland. Referred to as Gukurahundi ('the rain the washes away the chaff'), this period saw systematic violence perpetrated by the Zimbabwe National Army and the infamous Fifth Brigade from 1983-1987 to purge Matabeleland and Midlands provinces of 'dissidents'. Estimates put the death toll at between 8000 and 30,000 people, many of whom were civilians, while many more thousands were held and tortured in camps [60].

Embedded in social relations and places to enable responsiveness to change or stress [61], social farming practices have, in this way, been eroded by the forces of both modernisation and coercion, further compounding the erosion of social-ecological landscapes. Today, while the interlinking of cultural and spiritual traditions are intrinsic to traditionalists, this is not the case for Christians, many of whom reject the practice due to its association with beer brewing and traditionalism. Where ilima or humwe is still taking place today, it is more often seen as a practical exchange of labour than a performance.

\section{Methods}

This paper is interested in the extent to which agroecological practices, and emerging processes of co-enquiry and collective endeavour, can contribute to greater resilience by critically reframing social-ecological relationships based on a more plural and syncretic blending of traditions and knowledges. It then explores how changing attitudes might provide a countervailing force to a dominant culture of control as a foundation for bottom-up peace formation.

In investigating this, the paper draws on primary data from multi-site doctoral field research undertaken over nine months in Zimbabwe between 2016 and 2017 [62]. The research applied a political ecology lens, and a range of mixed methods leaning heavily towards the qualitative, using participatory action research to co-investigate the experiences of/with three agroecological communities of practice.

Drawn from agroecological farmers in each community, focus group discussions (FGDs) were attended by between twenty-five and thirty-eight participants, fairly equally by men and women, and up to one-third of whom were thirty-five years old and below, considered to be 'youths' (except in Matabeleland, where no youths attended). During these FGDs, participants described the pre-defined research concepts of resilience, agency and peace, resulting in the co-development and ranking of a series of bottom-up indicators. This process surfaced layers of experience for analysis. These indicators were then translated in to a series of survey questions, with response ranges drawn from FGDs and agreed by participants. As such, each survey posed different questions, highlighting different priorities between sites. Common survey questions appearing under resilience, however, ranged from productive diversity, seed saving, and experimentation; under agency these related to forms of co-operation, unity, leadership, and influencing (voice); and under peace were communication, trust and forms of coercion and / or violence (these are laid out for comparative analysis in Table 4). Surveys 
were then carried out with a total of 184 respondents, to explore how these were experienced in the everyday by others.

All survey respondents were smallholder farmers on communal or resettlement land, with samples containing marginally more women than men (up to one-third of whom were youths). Purposive samples were drawn from those directly engaged in agroecological activities, as recommended by focus group participants. Random sampling was undertaken in areas not directly exposed to agroecology activities, and where farmers were thought to be using only conventional approaches with related inputs. The responses were disaggregated by age, sex and farming typology, resulting in three broad typologies. Agroecological farmers were those who self-identified as organic (certified or otherwise), permaculture, agroforestry, or holistic land or livestock management practitioners, often in combination; Hybrid farmers were those who used organic practices, often for homestead production, and synthetic inputs for dryland cropping, or applied 'conservation farming' techniques; and conventional farmers were those using only synthetic inputs. This enabled a 'soft comparison' between typologies to consider emerging response patterns in farming 'cultures' and relationships. These quantitative data were then triangulated with qualitative data from FGDs and sixty-six interviews that were classified and coded to establish emerging patterns and divergences between the different research sites (identified by green markers on Figure 1).

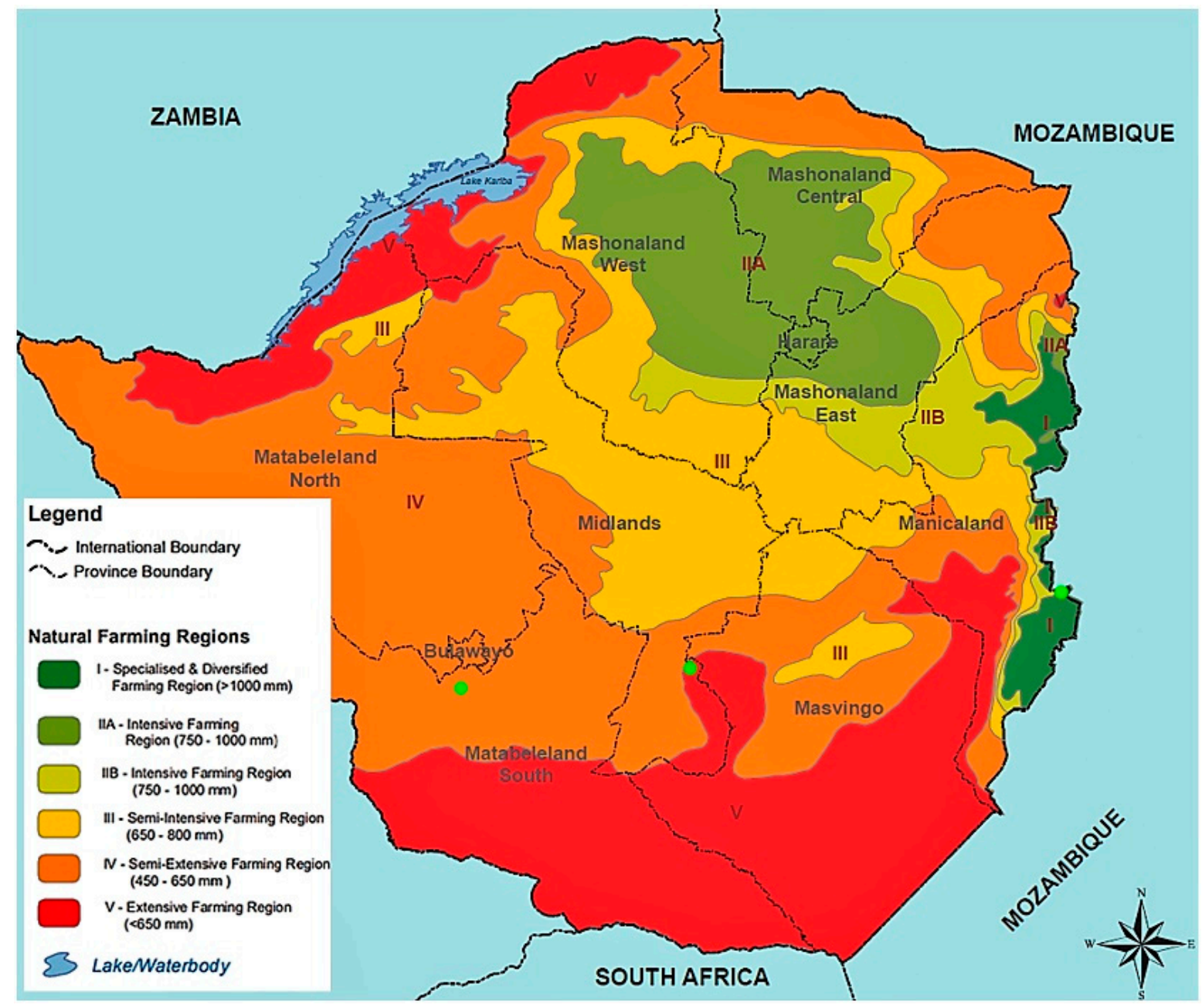

Figure 1. Zimbabwe's natural farming regions (source: OCHA, 2009)

Of the agroecological communities of practice contributing to this research, all sit within administrative wards of approximately 4000 people that, for different reasons, are at the margins of state service delivery. The first two, in Chikukwa and Mhototi, began as small groups of agroecological 
pioneers in the 1980s and 1990s. While each has experienced the erosion of traditional knowledge and related social farming practices, the local facilitating organisations, the Chikukwa Ecological Land Use Community Trust (CELUCT) and the Muonde Trust in Mhototi, both with permaculture roots, have a focus on knowledge recovery and relationship building. Chikukwa is situated in the high agricultural potential region (natural region-NR I) of the remote Eastern Highlands bordering Mozambique, receiving over $1000 \mathrm{~mm}$ of rain $\mathrm{p} /$ annum, and is considered appropriate for specialised and diversified farming. Mhototi lies in the semi-arid savannah of southern Zimbabwe (in NR V), receiving less than $450 \mathrm{~mm}$ of rain $\mathrm{p} /$ annum, and is considered appropriate for extensive livestock farming. Both are Shona-speaking areas and have historically been secure ZANU-PF constituencies, yet experience internal divisions and structural violence in the form of partisan distribution of welfare assistance, and campaigns of intimidation and violence during elections.

The third community, in Dema, has been engaged in an agroecology 'project' since 2010, with a focus on organic farming as a livelihood mechanism to instrumentalise peace. As a collaborative project between urban-based NGOs with international funding, its agroecology component is implemented by Fambidzanai Permaculture Centre, an NGO headquartered in Harare with a small local office in the district. Dema sits in NR IV, receiving approximately 450-650 $\mathrm{mm}$ of rain per annum and is considered suitable for semi-extensive farming. However, being in the heart of the spiritually important 'rain-giving' Matopos Hills, Dema enjoys higher rainfall and species diversity. Being a place of deep spiritual, cultural and ecological significance, the Matopos has also attracted intense missionary and military activity, and waves of displacement since early colonisation. Being in Ndebele-speaking Matabeleland, Dema was exposed to extreme levels of direct violence during the Gukurahundi campaign which continues to cast a long shadow. The area is one of the most closely contested parliamentary constituencies in Zimbabwe, held by ZANU-PF, yet at the time of this research had a majority opposition council, under the Movement for Democratic Change (MDC). Matabeleland continues to be exposed to high levels of structural and cultural violence, with historically lower levels of welfare assistance and development, and the suppression of cultural expression and identity.

Of the research sites, Dema was the most constricted in terms of civic activity, evident in the dearth of local organisations, while Chikukwa and Mhototi have the advantage of being sufficiently remote-further from the gaze of the centre and thus in the relative margins of freedom [63]. As such, the research differentiates between actively marginalised communities, and those left on the margins seemingly forgotten yet periodically manipulated.

\section{Research Findings}

Considerable variances between sites were found to have produced divergent realties and responses, due to historical influences, structural relationships, and agroecological modes of engagement. Furthermore, because a bottom-up approach to indicator development was central to participatory action research, each community chose different indicators. While this added texture for analytical depth, it makes simple data comparisons between sites more challenging. Common indicators and related data from survey responses have, nonetheless, been brought together in Table 4 . In focussing here on variations between agroecological and conventional farmers in each given area, it is possible to see how the different approaches have formed and been informed by divergent worldviews, and how this informs perceptions and attitudes to the environment and to one another. The second section brings these together to briefly consider the intersections between resilience, agency and peace according to the different socio-political and social-ecological conditions.

\subsection{Dema Community}

In Dema, conventional farmers were more dependent upon external inputs, with none saving seed. Whereas, $69 \%$ of agroecological farmers were saving seed, $81 \%$ were experimenting with different soil amendments, and $75 \%$ were applying integrated pest management techniques. Given these divergent approaches, agroecological farmers were considerably more predisposed towards social farming 
practices than conventional farmers, sharing knowledge, skills, labour, resources and equipment $(74 \%$ and $22 \%$, respectively). Correspondingly, twice as many agroecological farmers indicated that they were more tolerant of political, cultural and linguistic differences than conventional farmers. Despite being more critical of their local leadership, agroecological farmers indicated better interpersonal relations (from household to community level), had more voice, and felt less under threat from violence and discrimination (seen in Table 1).

Table 1. Examples of empirical evidence related to the common emergent properties identified by Dema Community.

\begin{tabular}{|c|c|}
\hline Common Emergent Properties & Examples of Empirical Evidence in Dema Community \\
\hline \multicolumn{2}{|l|}{ Resilience } \\
\hline Farming systems, scales and purpose & $\begin{array}{l}\text { Livelihood development to 'instrumentalise peace': Training hosted at six } \\
\text { disparate project gardens; honey production and vegetable processing. }\end{array}$ \\
\hline & $\begin{array}{l}\text { Skills transfer as a top-down technical intervention taking place at disparate } \\
\text { village gardens. Little known or shared locally of the rich farming traditions }\end{array}$ \\
\hline Plurality of knowledge applied & $\begin{array}{l}\text { of the area. Widespread rejection of traditional beliefs and related farming } \\
\text { practices locally. Agritex disengaged. NGO training as 'knowledge transfer'. }\end{array}$ \\
\hline Degree of self-reliance & $\begin{array}{l}\text { High dependency on state welfare and other external assistance. No attempt } \\
\text { at tree planting, ground cover or building strong structures to prevent cyclone } \\
\text { damage—assumed to be the responsibility of the state. Felt that wetland } \\
\text { management should be addressed through bylaws. }\end{array}$ \\
\hline \multicolumn{2}{|l|}{ Agency } \\
\hline Degree of efficacy & $\begin{array}{c}\text { Dema farmers least likely to anticipate or plan responses to stresses and } \\
\text { shocks-highly dependent on external services (state and NGOs) for food } \\
\text { security and mobilisation for development activities. Unable to envisage a } \\
\text { future or plan strategies. }\end{array}$ \\
\hline Degree of social farming & $\begin{array}{c}\text { Lower levels of social farming for exchange of seed or knowledge. 'Most of the } \\
\text { skills they are lost ... Some have died, some forget, some are in churches.' 'If you } \\
\text { collected a lot of people in what you were doing, they don't believe that you are } \\
\text { farming. They believed that you are ... agitating.' }\end{array}$ \\
\hline Networks coherence & $\begin{array}{l}\text { Little coherence, except for honey co-operative linking those engaged from } \\
\text { across villages. Wider activities tail off when funding ceases. }\end{array}$ \\
\hline \multicolumn{2}{|l|}{ Peace } \\
\hline Degree of everyday peace & $\begin{array}{l}\text { Higher-level threat dynamics in the area-described as political violence, } \\
\text { harassment, hatred, discrimination and fear. Leadership concerns identified } \\
\text { under peace due to being the perceived source of violence and social division. }\end{array}$ \\
\hline Degree of social cohesion & $\begin{array}{l}\text { Lower levels of social cohesion. Asked why 'trust' was not an indicator } \\
\text { during FGD: 'Ah no, that will take time. But it's slowly changing'. }\end{array}$ \\
\hline
\end{tabular}

In Dema, ilima was practiced by $45 \%$ of survey respondents overall. The reasons stated for its decline included an association with traditionalism and beer brewing deterring Christians from participating. Despite many agreeing with one farmer who said 'peace and working together go hand-in-hand', those interviewed who still practiced ilima explained that many no longer have the skills or knowledge about how to brew traditional beer, also central to the preparation and performance of traditional rituals. These tensions were also found to correlate with the decline in small grain production and thus resilience. The growth of the capitalist economy was also thought to have played a role, with many reporting that doing ilima was too expensive because it requires the host farmer to buy refreshments. Others said that it was more cost-effective to employ someone to come and do the work. However, protocols within groups also played a role, where reciprocity was seen less in the immediate term, but as part of a wider cycle, with one woman saying that if a family could not afford to provide refreshments that they would still gather and work. One innovative farmer talked excitedly about the re-introduction of ilima through the project, and explained the value of sharing:

When there's work in your field-but you can't afford with your family, then you call ilima so that people can come and help-they can come with their ideas. That's when you get information ... because when we do ilima we buy beer. So when people are wise they start 
to talk. Even hidden things. When he's wise now - when he takes wise water-he starts to share-'you know my friend, I've got something very precious'-like seed! [64]

And of course, the historical significance of a ban on public meetings in Matabeleland cannot be ignored. When asked about what had caused the decline of ilima, one elder said that ever since the liberation war: 'That's where most of the changes happened because when you did ilima you'd call a lot of people to help you. Then these army people came ... They would be thinking we were talking politics.' [65] Today, if public gatherings do not include the 'right people', it was thought to raise suspicion of subversive anti-government activity.

Of the research sites, the FGD participants and interviewees in Dema were the least likely to anticipate or plan responses to stresses and shocks. Little was known or shared locally of the rich and intricate Banyubi wetland farming traditions of the area [13]. Once dry for only three months of every year, and cropped with livestock rotations for the following nine, this picture has now reversed with the dry period lasting for nine months. Nonetheless, training tends to be a technical exercise that takes place at disparate village garden locations as a form of skills transfer. A reliance on external interventions and inputs, while lower for agroecological farmers, was nonetheless a recurring theme for the majority of farmers interviewed. A low sense of everyday peace was found in the selection of indicators that signalled higher-level threat dynamics associated with violence, harassment, discrimination and fear. This was found to constrain people's motivation to organise or engage in landscape-level activities, many of whom stated a fear of attracting the attention of factionalised leaders. Pressures to conform were found in a widespread rejection of traditional beliefs and related farming practices, with successful agroecological farmers reporting being routinely suspected of practicing witchcraft. The only sign of an emerging farmer-network was a bee-keeping and honey co-operative within the project that was linking people from across villages, prompting the beginnings of a concern about habitat loss and forage, and stimulating an interest in influencing landscape-level protection and rehabilitation.

\subsection{Mhototi Community}

In Mhototi, agrobiodiversity amongst conventional and agroecological farmers was found to be comparative. High levels of seed saving were found across Mhototi (98\% of all farmers). Being in the most arid environment, and with a training focus on water management, all agroecological farmers were experimenting with some form of surface rainwater capture for irrigation, and half had constructed dams that were reported to retain water for nine to eleven months of the year. Only $40 \%$ of conventional farmers reported having drain-away contours, and none were capturing run-off.

In developing water harvesting infrastructure and planting trees (see Table 2) agroecological farmers were building the confidence to shape their environment-creating micro-climates that extended the horticultural season and reduced inter-seasonal variability, providing further opportunities for diversification and experimentation with crops not previously grown in the area. A sense of efficacy was reflected in a stated ambition to fundamentally alter the agroecosystem. As such, agroecological farmers reported a pride in innovation; an enthusiasm for integrating traditional farming; and, more recently, were syncretically blending traditional rituals as part of the process of reforging social-ecological relationships. While little formal 'training' was being provided, the uptake of landscape-level activities by volunteer work groups had created a sense of common endeavour through farmer-to-farmer action learning. This also crossed over into, and integrates with, the advice of the local Agritex extension worker who received training in, and applies, organic farming on her own land and in her training with Master Farmers and at riverine Garden Clubs.

The highest level of social farming was found in Mhototi irrespective of farming typology, with between $71 \%$ and $100 \%$ of farmers sharing equipment, resources, labour, knowledge and skills. Agroecological farmers indicated better communication in the village and community than conventional farmers (63.5\% and $30 \%$, respectively). This pattern was also found in relation to unity at different levels of interpersonal relations and trust at community level, with agroecological 
farmers indicating that they experience less persecution, sickness and fewer food shortages. Here, an indicator was selected on 'unwanted development' that would pollute their environment or result in displacement, signaling a collective will and agency. Furthermore, while there was a unanimous response of the need to resist, more agroecological farmers felt that they had sufficient information and support from others in doing so.

During interviews in Mhototi, there was no automatic rejection of nhimbe as a traditional event at which beer is provided and no-one talked about a lack of reciprocity. While nhimbe traditions were thought by some to have been maintained by village heads, some respondents thought it was more recently reintroduced with agroecology activities. In his village, one farmer now makes an annual gesture to promote unity and understanding: 'As a good organic farmer, my crops ripen earlier than anyone else's. So I can take 10 cobs of maize and 10 sweet reeds to each and every member of the community... twenty-six households. And that helps to see that we are a community, we have to work as a community, and to share what we have in the community.' [66] While this demonstrates a single farmer's determination to unite people, this was echoed by others who were using shared knowledge, equipment and trade to bridge divisions.

Table 2. Examples of empirical evidence related to the common emergent properties identified by Mhototi Community.

\begin{tabular}{lc}
\hline Common Emergent Properties & Examples of Empirical Evidence in Mhototi Community \\
\hline Resilience & To manage drought and worsening economic hardship: Water \\
Farming systems, scales and purpose & $\begin{array}{c}\text { harvesting and dams at farm level, expanded to landscape-level } \\
\text { drystone walling, tree planting and bio-cultural resource monitoring } \\
\text { for protection by volunteer work groups. }\end{array}$ \\
Plurality of knowledge applied & $\begin{array}{c}\text { History of action research with external influences to restore local } \\
\text { knowledge and spread innovations farmer-to-farmer. Gradual } \\
\text { institutional acceptance and integration with Agritex advice. }\end{array}$ \\
& Almost all farmers saving seed and producing small grains for \\
drought tolerance. Majority of agroecological farmers managing & surface water for irrigation and diversification.
\end{tabular}

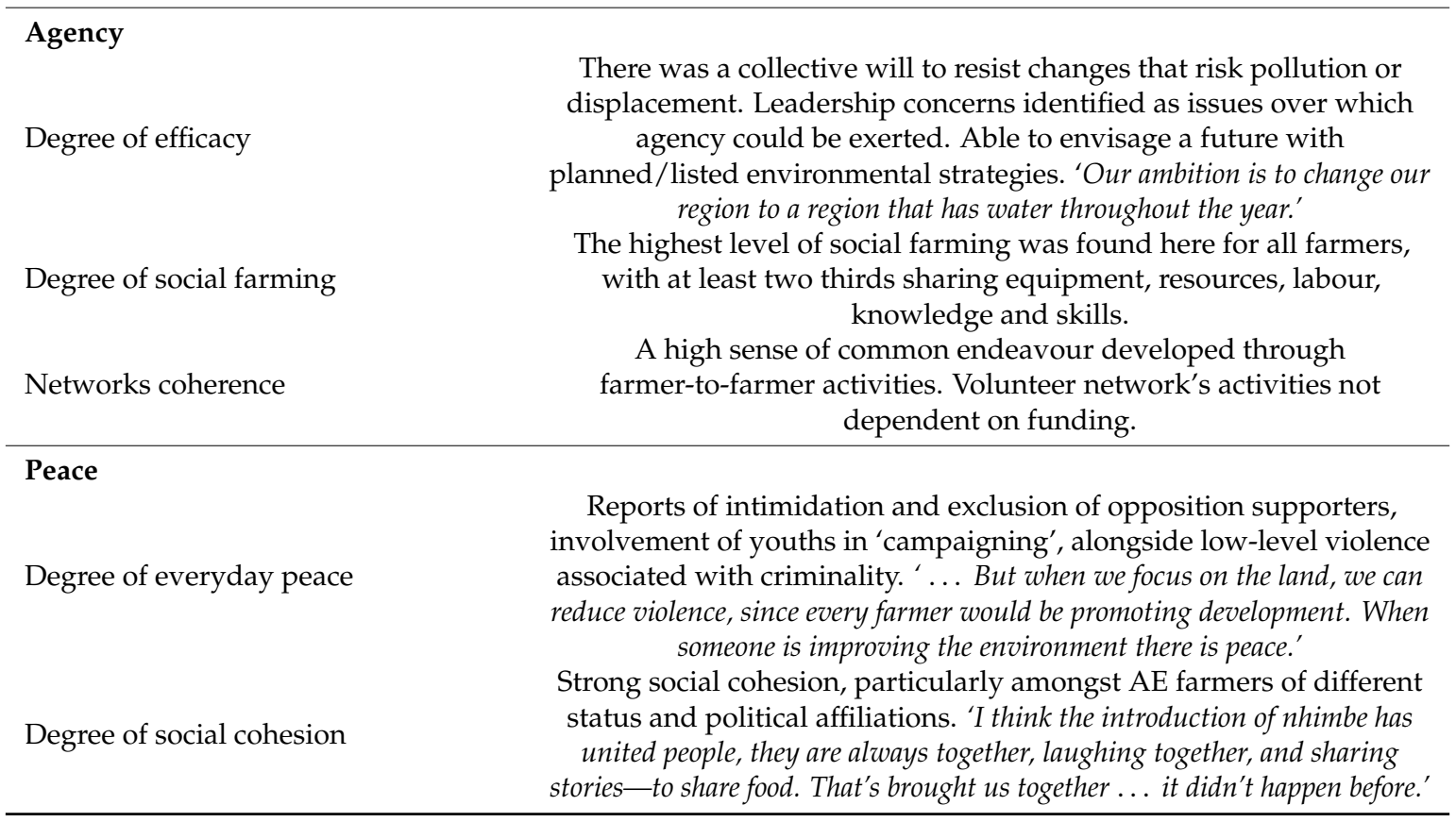




\subsection{Chikukwa Community}

In Chikukwa, while 70\% of conventional farmers were cultivating 6-10 different crop types and varieties, $61 \%$ of agroecological farmers were cultivating between 6 and more than 25 crops. A similar pattern was seen for seed saving, with $61 \%$ of all farmers saving $4-8$ types, but with more agroecological farmers saving 9-15 and 16-20. Pests and diseases were considered a constant problem for $40 \%$ of conventional farmers and only $13 \%$ of agroecological farmers. Correspondingly, $60 \%$ of conventional farmers indicated that they needed to purchase more food from the shops but could not afford to. Farmers in Chikukwa were more likely to engage in collective production at the chief's field than traditional labour sharing arrangements such as nhimbe, which was rarely practiced. However, seed, information and skills sharing between agroecological farmers was taking place at gardens and nurseries in each village. In the Chikukwa survey, agroecological farmers therefore indicated higher levels of self-confidence, felt more united as a community, and felt more respected and able to influence decisions within their villages and ward. Conversely, $90 \%$ of conventional farmers said that they experienced no peace of mind from persecution (noted as witchcraft or jealousy); $40 \%$ indicated that they found it difficult to trust others; and $60 \%$ found it difficult to tolerate people with different belief systems.

Chikukwa's agroecological work (see also Table 3), resulting from periods of environmental shock, was said to have united people within and across its villages around landscape-level changes-initially creating networks to dig contours for terracing, tree planting, gulley reclamation and spring restoration. As well as leading to rapid livelihood improvements, these agroecological processes encouraged greater awareness of, and responsiveness to, social change and tensions as a result of inward migration caused by periods of economic and political upheaval that nonetheless continue to present challenges. Additionally, more recent participatory seed breeding, soil and pest management initiatives have started to reinvigorate farmer-to-farmer learning and experimentation to increase resilience to climate change.

The accounts of three community leaders participating in evolving and inter-connected initiatives demonstrated that their world views were radically altering, and this translated into higher levels of empathy, shifts in patronage practices and attitudes to inclusiveness. When asked how their perspectives had changed, the two traditional leaders said that, in the past:

'If there was some food aid—out of 20 bags I'd grab five-I could take it 'cause I' $m$ the leader. I didn't know that there is a sense of greed in us that you might not notice- you just think it's your right. I was such an angry person ... I used to even beat my children. That stick that I beat my child with, what kind of pain was I causing my child?' [67]

'I was a very hard man. Since I'm a [headman] people must respect me ... I'm a big traditional man. I'm second to the chief! People were afraid of me. But here, I learned that everyone is the same-everyone should be respected. And by so doing, I now manage to talk to everybody. Now I am a better leader.' [68]

An elected ZANU-PF ward councilor reaching the end of his fixed-term had used the dialogical tools learned in Chikukwa to begin planning his succession with cross-party consultations to ensure that, whatever the election outcome, the work of the village and ward committees were able to continue without the usual political upheaval. When asked the same question, he said, 'I was a bully-a black belt in karate. I was so quick to temper, and didn't want to be disrespected. But now I'm engaged and friendly-and am able to focus on my work.' [69]

In another case, one farmer who had prepared his land for planting and having been accused of being an opposition supporter, was then refused seed being distributed from the government. Left destitute, he was approached by a ZANU-PF supporting seed guardian and agroecological pioneer who shared her open pollinated varieties with him. That year, he achieved impressive yields and has never looked back. As echoed in other stories, they are now working together as seed guardians and village trainers, united instead by how they farm and what they save and share with others. 
Table 3. Examples of empirical evidence related to the common emergent properties identified by Chikukwa Community.

\begin{tabular}{|c|c|}
\hline Common Emergent Properties & Examples of Empirical Evidence in Chikukwa Community \\
\hline \multicolumn{2}{|l|}{ Resilience } \\
\hline Farming systems, scales and purpose & $\begin{array}{l}\text { To manage soil loss, land degradation and drying springs: Terracing, } \\
\text { tree planting, gully and spring reclamation, village gardens and } \\
\text { nurseries managed by integrated village committees. }\end{array}$ \\
\hline Plurality of knowledge applied & $\begin{array}{l}\text { History of pioneer agroecological activity, initially from external } \\
\text { sources. Knowledge generated from collectively planned actions } \\
\text { and restoration of cultural farming and traditions. Participatory } \\
\text { farmer-to-farmer learning and experimentation. Development of } \\
\text { knowledge 'like peeling an onion.' Agritex buy-in. }\end{array}$ \\
\hline Degree of self-reliance & $\begin{array}{l}\text { Two thirds of all farmers saving } 4-8 \text { seed types. New varieties } \\
\text { introduced to diversify food and trade opportunities. Seed breeding, } \\
\text { saving and sharing, and soil and pest management initiatives. }\end{array}$ \\
\hline \multicolumn{2}{|l|}{ Agency } \\
\hline Degree of efficacy & $\begin{array}{c}\text { Leadership concerns identified as issues over which agency could be } \\
\text { exerted. Able to envisage a future with planned/listed inter-linked } \\
\text { environmental and social strategies. }\end{array}$ \\
\hline Degree of social farming & $\begin{array}{l}\text { Farmers were found to be more likely to engage in collective } \\
\text { production at the chief's field. Village gardens instead providing } \\
\text { source of knowledge and seed sharing for network members. 'There } \\
\text { is that unity of purpose with the organic farmers, it's like a } \\
\text { community - they come together.' }\end{array}$ \\
\hline Networks coherence & $\begin{array}{c}\text { Agroecological work united people within and across villages } \\
\text { around landscape-level changes and expanded to village conflict } \\
\text { management and social support groups. AE village activities not } \\
\text { dependent on external funding. }\end{array}$ \\
\hline \multicolumn{2}{|l|}{ Peace } \\
\hline Degree of everyday peace & $\begin{array}{l}\text { Exclusion of opposition supporters and involvement of youths in } \\
\text { election campaigning. More police harassment reported by AE } \\
\text { farmers due to higher engagement in trade. Accounts of shifting } \\
\text { world views resulting from inter-linked community peace work: } \\
\text { 'I didn't know that there is a sense of greed in us that you might not } \\
\text { notice-you just think it's your right. I was such an angry person.' }\end{array}$ \\
\hline Degree of social cohesion & $\begin{array}{l}\text { High levels of cohesion and embeddedness of AE farmers within } \\
\text { leadership reported-more able to resist political pressure. }\end{array}$ \\
\hline
\end{tabular}

\subsection{Intersections between Resilience, Agency and Peace}

Drawing together responses that intersect resilience, agency and peace from focus group discussions and interviews from all three sites, a common refrain was that, 'without food there is no peace', with the lack of food cited as a common source of tension and conflict in the household. The benefits of autonomy over food production were found to be far reaching. As pointed out by one respondent and echoed across all the sites: 'I don't have to elect a particular party because I'm hungry or need inputs. If I'm in control I can vote for who I want. So it gives you power' [70]. Conversely, more atomised conventional farmers in Dema and Chikukwa, and those agroecological farmers with poor agrobiodiversity, were found to be more dependent on welfare or shop-purchased food and farming inputs and were routinely exposed to price fluctuations, disreputable middlemen and/or inequitable patronage relations, reporting higher levels of mistrust and suspicion (seen in Table 4).

There was evidence of the development of adaptive capacity through experimentation. This was visible in activities that had re-shaped the landscape, and where learning was embedded in cultural practices and reinforced through co-learning and sharing at homestead or village locations. Conversely, seed saving was notably lower where a mistrust of tradition and social farming practices was higher. In Dema, only 53\% of all farmers saved any seed, many of whom reported that they lacked the skills or relationships to explore this in any detail. In Chikukwa and Mhototi, this figure was almost $100 \%$. 
Small grains, such as varieties of sorghum or millet, are particularly important in the lower-potential regions. Furthermore, while these were distributed in Dema and Mhototi, only a third of farmers were producing small grains in Dema, where farmers reported bird damage and associations with traditionalism as being a disincentive. However, in Mhototi almost all respondents were producing sorghum and varieties of millet and were mitigating bird damage by widespread planting through collective farming practices.

Acts of reciprocity, both pragmatic and open-ended, were concentrated amongst agroecological farmers, and included sharing resources such as seed and knowledge. These farmers did not limit these actions only to other agroecological farmers, and told stories of empathy and sharing that united people across divides. In stark contrast, competitive modes of farming promoted through conventional farming approaches were thought to have contributed to a sense of mistrust. This was highlighted by the Agritex officer in Chikukwa, for whom the different attitudes between farmers were marked:

'So suspicion in is very high. Yesterday we were talking about forming these groups-I was trying to tell them about avoiding mistrust - so that they can form groups for bargaining purposes. Having a rep will benefit you.... When we are looking at the organic [farmers], they are more on the ground. They feel like they are more accommodated by each other. They share their ideas. They come together. There is that unity of purpose. When it comes to these competitions, it's conventional [farmers] that thrive there. But with the organic farmers, it's like a community-they come together. That is my observation-they work together so they tend to be closer. They depend upon each other to build their assets.... The conventional farmers don't do that.' [71]

Table 4. Quantitative data resulting from the common thematic indicators selected by focus groups $(\mathrm{CF}=$ conventional farmers, $\mathrm{AE}=$ agroecological farmers, and $\mathrm{NR}=$ agroecological region/zone $)$.

\begin{tabular}{|c|c|c|c|}
\hline \multirow{2}{*}{$\begin{array}{l}\text { Common Indictors by } \\
\text { Research Theme }\end{array}$} & \multicolumn{3}{|c|}{ Case Study Area } \\
\hline & Dema (NR IV) & Mhototi (NR V) & Chikukwa (NR I) \\
\hline \multicolumn{4}{|l|}{ Resilience } \\
\hline $\begin{array}{l}\text { Productive diversity-crop } \\
\text { types and varieties }\end{array}$ & $\begin{array}{c}100 \% \text { of CFs / } 94 \% \text { of } \mathrm{AE} \\
\text { cultivating } 2-15 .\end{array}$ & $\begin{array}{c}80 \% \text { of } \mathrm{CF} / 83 \% \text { AE cultivating } \\
2-15 .\end{array}$ & $\begin{array}{l}70 \% \text { of CFs cultivating } 6-10 / 61 \% \\
\text { of AE farmers cultivating } 11-25 \text {. }\end{array}$ \\
\hline $\begin{array}{l}\text { Seed saving-types and } \\
\text { varieties }\end{array}$ & $\begin{array}{c}69 \% \text { of AE farmers saving seed. } \\
\text { No CF saving seed. }\end{array}$ & $\begin{array}{l}\text { 100\% CF saving 4-15 / 98\% AE } \\
\text { saving 4-20. }\end{array}$ & $\begin{array}{c}70 \% \text { CF saving } 4-15 / 91 \% \text { of } \mathrm{AE} \\
\text { farmers saving } 4-20 .\end{array}$ \\
\hline Small grains—sorghum & $\begin{array}{c}30 \% \text { of all farmers cultivating } \\
\text { small grains }\end{array}$ & $94 \%$ AE farmers $/ 90 \% \mathrm{CF}$. & $\begin{array}{c}\text { Small grains not selected due } \\
\text { to NR. }\end{array}$ \\
\hline Experimentation & $\begin{array}{l}\text { NPM: } 36 \% \text { CF / } 75 \% \mathrm{AE} ; \\
\text { organic soil amendments: } 81 \% \\
\text { AE / CF none. }\end{array}$ & $\begin{array}{c}\text { Water harvesting-Infiltration: } \\
20 \% \mathrm{CF} \text { / } 67 \% \mathrm{AE} \text {; diversion } \\
\text { drains and dams: } 60 \% \mathrm{AE} / \mathrm{CF} \\
\text { none; }\end{array}$ & $\begin{array}{c}\text { Organic soil amendments: } 10 \% \text { CF } \\
\text { / } 96 \% \text { AE; pests and diseases } \\
\text { constant: } 40 \% \text { CF / 13\% AE. }\end{array}$ \\
\hline \multicolumn{4}{|l|}{ Agency } \\
\hline Co-operation and sharing & $\begin{array}{c}\text { Ilima: } 45 \% \text { of all farmers; } \\
\text { Knowledge: } 27 \% \text { CF / } 94 \% \text { AE; } \\
\text { Info: } 9 \% \text { CF / } 56 \% \text { AE; Labour } \\
\quad 9 \% \text { CF / } 63 \% \text { AE. }\end{array}$ & $\begin{array}{c}\text { Nhimbe: } 95 \% \text { of all farmers; } \\
\text { Knowledge: } 90 \% \text { CF / 98\% AE; } \\
\text { Info: } 80 \% \text { CF / 90\% AE; Labour: } \\
\text { 90\% CF / } 88 \% \text { AE. }\end{array}$ & $\begin{array}{c}\text { Participation together in } \\
\text { community activities: } 20 \% \mathrm{CF} / \\
57 \% \mathrm{AE} .\end{array}$ \\
\hline Unity & $\begin{array}{l}\text { As a community: } 18 \% \mathrm{CF} / \\
38 \% \mathrm{AE} ;\end{array}$ & As a village: $\mathrm{CF} 40 \%$ / $81 \% \mathrm{AE}$ & $\begin{array}{c}\text { As a community: } 57 \% \mathrm{CF} / \\
86 \% \mathrm{AE} ;\end{array}$ \\
\hline $\begin{array}{l}\text { Decision-making and } \\
\text { Influencing }\end{array}$ & $\begin{array}{l}\text { Listened to in } \\
\text { household/family: } 45 \% \mathrm{CF} / \\
75 \% \mathrm{AE} \text {; Confidence in village } \\
\text { meetings: } 36 \% \mathrm{CF} / 69 \% \mathrm{AE} \text {. }\end{array}$ & $\begin{array}{l}\text { Listened to by village heads: } 40 \% \\
\text { CF / } 76 \% \text { AE; Able to make } \\
\text { land-use decisions: } 60 \% \mathrm{CR} / 60 \% \\
\text { AE (more women than men). }\end{array}$ & $\begin{array}{l}\text { Able to influence village: } 30 \% \mathrm{CF} \\
\text { / } 61 \% \mathrm{AE} \text {; Ability to make all } \\
\text { planting decisions: } 10 \% \mathrm{CF} / 57 \% \\
\text { (more women than men) }\end{array}$ \\
\hline \multicolumn{4}{|l|}{ Peace } \\
\hline Good Communication & $\begin{array}{c}\text { As a community: } 27 \% \text { CF / } 75 \% \\
\text { AE. Tolerance: different political } \\
\text { opinions } 36 \% \text { CF / } 69 \% \text { AE; } \\
\text { cultural difference } 45 \% \text { CF / } \\
100 \% \text { AE. }\end{array}$ & $\begin{array}{c}\text { As a village: } 20 \% \mathrm{CF} / 79 \% \mathrm{AE} \text {. } \\
\text { (Tolerance or its absence was not } \\
\text { raised) }\end{array}$ & $\begin{array}{c}\text { 'As neighbours': } 70 \% \text { CF / } 91 \mathrm{AE} \text {. } \\
\text { Tolerance of different beliefs: } 65 \% \\
\text { AE / } 60 \% \text { CF found difference } \\
\text { 'difficult to tolerate'. }\end{array}$ \\
\hline Trust & 'Trust' was an absent indicator. & $\begin{array}{c}\text { As a community: } 10 \% \mathrm{CF} / \\
33 \% \mathrm{AE} \text {. }\end{array}$ & $\begin{array}{c}\text { As a community: } 30 \% \mathrm{CF} / \\
57 \% \mathrm{AE} .\end{array}$ \\
\hline Coercion / violence & $\begin{array}{c}60 \% \text { of total felt under threat of } \\
\text { political violence: } 73 \% \text { CF / } 38 \% \\
\text { AE. } 70 \% \text { subjected to } \\
\text { discrimination on political } \\
\text { grounds: } 82 \% \text { CF / } 50 \% \mathrm{AE} \text {. }\end{array}$ & $\begin{array}{c}68 \% \text { said officials were } \\
\text { factionalised ( } 50 \% \text { CF / 69\% AE); } \\
\text { Awareness of political violence: } \\
60 \% \text { CF / } 54 \% \text { AE. }\end{array}$ & $\begin{array}{c}\text { Police harassment: } 30 \% \text { CF / } 65 \% \\
\text { AE; awareness of political } \\
\text { coercion: } 40 \% \text { CF / } 61 \% \text { AE; } \\
\text { Ability to resist political pressures: } \\
\text { 30\% CF / 70\% AE. }\end{array}$ \\
\hline
\end{tabular}




\section{Discussion: Reforging Social-Ecological Relationships for Peace Formation}

\subsection{Agency for Resilience}

As stated by people in both Chikukwa and Mhototi, periods of political and economic stress and environmental shock marked key-changes. These were found to have resulted in a process of creative re-visioning and direct action, freeing people to experiment and take risks, and to imagine alternative pathways. Yet the condition of Dema proves instructive where marginalisation has amplified cumulative stresses punctuated by shocks with such increasing regularity and severity that there is a sense of numbing. Under such conditions, responsiveness may not always be possible, particularly in situations where levels of destabilisation have crossed a critical threshold beyond which a system cannot self-organise around a different trajectory [72,73]. Here, more extreme levels of coercion and socialised consent may render responsiveness untenable, combining to form an impenetrable crust of pathological resilience to change [74]. This suggests that shock alone is not a sufficient stimulus for transformation and that resilience is less a function of scarcity per se, but of historical factors and the broader sets of power relations they reproduce. As such, resilience and its attendant responsiveness need to be viewed through different lenses, 'rooted in local histories and societies, yet connected to larger processes of material transformation and power relations.' [11] (p. 25).

The research was interested in the development of adaptive capacity as an emancipatory process. This was established through interviews and observations, considering: the integration of farming systems and knowledge, new innovations, and/or experimentation/adaptation of previous innovations. Of the farmers interviewed, half of those in Chikukwa and Dema were actively experimenting, as were almost all of those in Mhototi, irrespective of any explicit support for more experimental farming systems. Of this group, referred to as innovators, all the farmers embraced complexity and enjoyed substantially higher agrobiodiversity and yields, which they also associated with enabling greater autonomy. Significantly, this group was found to be more socially active and highly inquisitive in their quest for information and seed gathering/sharing; were confident and comfortable linking the past to the present with reference to different techniques and belief systems; and were most often politically agnostic, swimming against a strong technocratic and, in some cases, highly coercive tide with a healthy dose of cynical humour. Experimentation, whether this resulted in new innovations or adaptations based on blended knowledge, was found to be producing an energy and optimism, seen in the ability to envision and plan for the future.

In both Chikukwa and Mhototi, exposure to external action researchers has contributed to an enthusiasm for knowledge restoration and indigenous innovation. In Mhototi, this was stimulated by the influential work of local 'water harvester' Zephaniah Phiri since the 1960s, [75] prompting visits by prominent agroecologists and doctoral researchers since the 1980s. These interactions have shaped a responsiveness to change through shared learning, within which the networks were invested and united. As a result of either water harvesting practices (Mhototi) or strategies for learning (Chikukwa), groups from across Zimbabwe and beyond visit for farmer-to-farmer learning, further exposing network members to different ways of being and thinking. This has contributed to a sense of pride and confidence, and continues to inform strategies through which change is being negotiated.

The story of knowledge loss and its recovery were seen in parallel with the critical loss of agency and, along with it, resilience, leaving people precariously exposed to the less desirable forces of change. Where structural violence and knowledge erosion were found most acutely in combination, there were correspondingly low levels of adaptive capacity, a high dependence on external assistance and vulnerability to manipulation and stress. Furthermore, the effects of cultural power exerted through dominance over discursive practices were particularly pronounced where structural bias and power asymmetries were found in the denouncement of traditional practice and belief.

Conversely, when aligned with more plural knowledge sources, a growing sense of efficacy was found to open opportunities for exchanges that underpin the dynamic process of exploration and knowledge co-generation, in an entirely heurist and iterative performance to reinvigorate the embrace 
of social-ecological complexity. The study found that knowledge recovery and its syncretic blending with plural ways of knowing and doing, as a conscious process of re-membering, and who defines it, has profound implications for everyday peace. In Chikukwa, changing worldviews were leading to a radical shift from a culture of control to one of responsiveness and care. As such, the process of building confidence to question holds the potential to be restorative in the face of historical political and epistemic injustices, and opens a space within which more recent injustices and violence may be articulated.

\subsection{Transforming Relationships through Collective Endeavour}

Across study sites, social farming systems were found to be central to the majority of self-identified agroecological farmers. This was considered to be the result of more labour- and knowledge-intensive farming practices, within which positive peaceful relations based on reciprocity and trust were being reforged. The application of these systems was found to vary between sites according to patterns of agrarian change, as in Chikukwa, where the creation of village gardens and nurseries were providing alternative focal points for meeting and exchange between agroecological farmers. Furthermore, where nhimbe or ilima was explicitly practiced, the values embedded within culture were most often viewed as a function of non-monetary social relations concomitant with social capital. These were found to incorporate an element of social protection against structures of domination, yet also served as a function of the relationship between members of the household and social networks [76] (p. 97).

Where agroecological communities were working collectively across their agroecosystems, the incremental attainment of desired outcomes through collective action was building confidence in group activity for further generative relational change. Furthermore, where this was lacking, as in Dema, respondents were more often found to express feelings associated with being products of, or prisoners to their socio-political and natural environment, and were more prone to pessimism and erratic decision-making, with corresponding impacts on resilience.

In Mhototi and Chikukwa, however, agroecological farmers were using sharing and empathy to cut through tensions and were actively building bridges. Furthermore, while the relationship between social and financial capital has not always been clear, it was found that farmers were able to cultivate their social connections for reciprocity. Related benefits included resource sharing and trade, with even the most resource-poor agroecological farmers successfully building their asset-base, social standing and capacity for participation [77].

Closely linked to solidarity, the importance of trust to the formation of a common endeavour was found to be highly prized in agroecological communities, increasing a sense of belonging despite differences. This solidarity around agroecological farming systems was found to cut across vertical cleavages of culture, language, religion or party politics, framed instead around uniting behind land-use practices or bio-cultural resource protection. These characteristics were found more prominently where landscape activities had created a sense of collective endeavour, forming alternative sources of power and identity. This unity of purpose was found to have implications for building relationships and obligations-activities around the achievement of which were found to further strengthen solidarity, forming a virtuous circle of social-ecological change.

\subsection{Implications for Building a Just Peace}

Often formed around the resources for everyday survival, the apparently disparate acts of defiance-found in inherently creative and exploratory social farming-taking place at the margins were of relevance precisely because they allow us to view everyday social practices as an expression of resistance and agency in a way that transcends the limiting binaries of active or passive, individual or collective, civil or political. In this way, a large number of people with shared knowledge and practices embody a social change which seeks to reclaim power in seemingly non-ideological ways, yet these non-movements have distinct identities, propelled by 'a type of fluid, flexible, and self-producing strategy' [78] (p. 14). Here, it is also important to acknowledge that emerging networks, within which 
an emancipatory ethic is not embedded, may be just as likely to reproduce dominant epistemologies and power structures. Equally, interventions that avoid engaging with structures of domination and social justice, focussing instead on individualised technical resilience strategies as part of a post-political discourse, may fail to create alternative sources of power that generate social change.

The agility of these networks, the acceptance of more plural approaches over time through engagement with local state institutions and service providers, while navigated with considerable caution, had served to increase agroecological coverage to reduce differences between the performance and experiences of agroecological and conventional farmers discussed here. In this way, social benefits were extending beyond agroecological networks, as in Mhototi.

In Chikukwa, the social capital generated through its network has stimulated civic engagement with existing structures, with members increasingly embedded in leadership positions and able to influence decision-making processes. Furthermore, creative approaches, evolving from its agroecological work have opened up new areas of engagement. More recently, this had translated to research on cultural practices for social-ecological protection against emerging threats, women's groups to address gender-based violence, and a platform through which resource users' voices were being heard by its traditional leadership as they develop environmental management plans. What has emerged is a dialogical approach, embedded in socio-cultural traditions, with a focus on trust-building and relationship transformation creating new ways of thinking, knowing and doing, and opening up a space where sensitive matters are discussed more openly, mediated through different networks and village structures.

By cautiously edging open these contested spaces, to differing degrees, agroecological networks pushing against boundaries were expanding out from their initial farming focus to explore interrelated social challenges in the midst of a complex combination of social, political, economic and environmental drivers. By strengthening critical agency for the representation of the most marginalised, harnessing the adaptation process of collective experience and reflection, the social-ecological and its inherently political dimensions were being tentatively bridged through discursive practice and idiomatic expressions rooted in culture and place.

The emergence of these levels of engagement demonstrates the importance of creating and supporting structures that are representative and responsive in real time, as a form of bottom-up process of peace formation which is unscripted and emancipatory. Occurring simultaneously and in parallel with more formal processes, representing a 'contextual legitimacy' which might be more intrinsically stable [32], these processes, while perhaps never entirely free of power reproduction, serve as a moderating role between a liberal top-down homogenising technocracy, and the exclusionary tendencies of the customary.

\section{Conclusions}

While this is the first time that agroecology has been brought together with peacebuilding, this study is nonetheless based on only three case studies in a single country, representing a snapshot in time, and with relatively small cohorts of farmers. These caveats notwithstanding, the results have indicated some interesting new phenomena: specifically, the role of opening more plural knowledge pathways to stimulate confidence to address change and complexity in violent environments; and the value of social farming in re-forging relationships that are capable of bridging divisions.

In investigating the potential of agroecology, as people-centred rural peacebuilding praxis to unite people in creative and inherently social farming acts, this paper has shown that social farming was reforging relationships in Chikukwa and Mhototi. In Dema, however, not only were these processes not central to the more normative approach taken by the project; the more extreme levels of structural and direct violence that have heightened dependence on the state have served to reduce farmers' capacity and motivation to develop a collective response. This has left people in Dema highly exposed to the less desirable forces of change. Yet this research also demonstrates that, where it was taking place, collective endeavor was creating alternative sources of identity in the form of landscape-level 
restoration-a process which was stimulating a renewed sense of agency to negotiate and manage social change, by increasing people's capacity and confidence for critical questioning.

By presenting quantitative data on facets of social capital-including unity, trust and tolerance-together with supporting accounts, this paper demonstrates pathways for gradual transformations away from habituated cultures of control, towards greater responsiveness through the culturing of plural ways of knowing and doing and, ultimately, driving towards mutualities of care [36]. In creating conditions for a flourishing of possibility within which the constrictive boundaries are being recursively tested [37], a return to social farming systems was found to enhance resilience, emerging through an exploration of traditional knowledge and farming practices, and creating a new-found confidence to test new ideas. This suggests a linking of past-present-future relationships, within which experiences and expressions associated with social capital were in evidence. Indeed, the characteristics of social capital are also characteristics of civility and positive peace.

These culturings of transformative social change [36] were found more prominently where agroecology was being applied in its open-ended form that created spaces for co-learning and experimentation within which relationships, with one another and with nature, were being explored collaboratively. The non-movements that Asef Bayat refers to as being part of a quiet encroachment of the ordinary [78] (p. 54) may be an entirely pragmatic response, particularly where civic spaces are highly constricted and/or contested, and where organisations move beneath the radar to deliver seemingly benign training. However, externally devised and normative resilience strategies for food and livelihood security in the attainment of peace were unable to transform the relationships around those structures when simultaneously failing to address the needs associated with recognition, security, and identity [79]. This is because a focus on technical 'delivery' for resilience or sustainability risks diverting attention from what is essentially a more plural and emancipatory agenda that is otherwise found in the altogether more risky business of recursive questioning for transformative change. Re-storying the past by recovering knowledge as a conscious process of re-membering disaggregated and subordinated subjectivities, and who defines it, has profound implications for everyday peace. As such, it holds the potential to be restorative in the face of historical, political and epistemic injustices, and opens a space within which more recent injustices and violence may be addressed.

What becomes clearer from this study is that agroecological organisations can more effectively generate confidence by exposing their networks to plural ways of thinking and acting to increase responsiveness based on relationships rooted in place and culture. This was found to be an important first step. Where this was taking place, agroecological farmers were exploring collective actions to restore their wider agroecosystems, forming tight bonds of solidarity and trust. In the process, they were increasingly able to envisage a future together shaped instead by their changed horizons and collective vision, with transformative effects on relationships between people and their landscapes.

Author Contributions: G.M. contributed research methodology, investigation and validation, analysis, data curation and original draft preparation. J.W. contributed data tabulation. Both authors contributed to conceptualisation, review and editing.

Funding: This research received no external funding.

Conflicts of Interest: The authors declare no conflict of interest.

\section{References and Notes}

1. Scoones, I.; Edelman, M.; Borras, S.M., Jr.; Hall, R.; Wolford, W.; White, B. Emancipatory rural politics: Confronting authoritarian populism. J. Peasant Stud. 2017, 45, 1-20. [CrossRef]

2. Fund for Peace. Fragile States Index. 2018. Available online: http://fundforpeace.org/fsi/ (accessed on 17 August 2018).

3. Homer-Dixon, T.F. Environment, Scarcity and Conflict; Princeton University: Princeton, NJ, USA, 1999.

4. Trottier, J. Water Wars: The Rise of a Hegemonic Concept. Exploring the Making of the Water War and Water Peace Belief within the Israeli-Palestinian Conflict; PCCP Series 6.8; UNESCO: Paris, France, 2003. 
5. Asaf, Z.; Schoenfeld, S.; Alleson, I. Environmental Peacebuilding Strategies in the Middle East: The Case of the Arava Institute for Environmental Studies. Peace Confl. Rev. 2010, 5, 46-62.

6. Fischhendler, I.; Dinar, S.; Katz, D. The politics of unilateral environmentalism: Cooperation and conflict over water management along the Israeli-Palestinian border. Glob. Environ. Politics 2011, 11, 36-61. [CrossRef]

7. Buckles, D.; Rusnak, G. Conflict and Collaboration in Natural Resource Management; The International Research Development Institute: Ottawa, ON, Canada, 1999.

8. Martin, A.; Rutagarama, E.; Cascao, A.; Gray, M.; Chhotray, V. Understanding the co-existence of conflict and cooperation: Transboundary ecosystem management in the Virunga Massif. J. Peace Res. 2011, 48, 621-635. [CrossRef]

9. Ali, S.H. Transboundary Conservation and Peacebuilding: Lessons from Forest Conservation Biodiversity Project; UNU-IAS Policy Report; United Nations University: Trigo, Macau, April 2011.

10. Bohle, H.G.; Fünfgeld, H. The political ecology of violence in eastern Sri Lanka. Dev. Chang. 2007, 38, 665-687. [CrossRef]

11. Peluso, N.L.; Watts, M. Violent Environments; Cornell University Press: Ithaca, NY, USA, 2001.

12. Kriger, N.J. The Zimbabwean war of liberation: Struggles within the struggle. J. South. Afr. Stud. 1988, 14, 304-322. [CrossRef]

13. Ranger, T.O. Voices from the Rocks. Nature, Culture and History in the Matopos Hills of Zimbabwe; James Currey: Oxford, UK, 1999.

14. Alexander, J. Things fall apart, the centre can hold: Processes of post-war political change in Zimbabwe's rural areas. Occas. Pap. 2014, 8, 131-162.

15. Ndlovu-Gatsheni, S.J. Do 'Zimbabweans' Exist? Trajectories of Nationalism, National Identity Formation and Crisis in a Postcolonial State; Peter Lang: Bern, Switzerland, 2009; Volume 3.

16. Newsham, A.; Kohnstamm, S.; Otto Naess, L.; Atela, J. Agricultural Commercialisation Pathways: Climate Change and Agriculture; APRA Brief 6; Future Agricultures Consortium: Brighton, UK, 2018.

17. Galtung, J. Violence, Peace, and Peace Research. J. Peace Res. 1969, 6, 167-191. [CrossRef]

18. Altieri, M.A. Agroecology: The Science of Sustainable Agriculture; CRC Press: Boca Raton, FL, USA, 2018.

19. Uphoff, N. Opportunities for Raising Yields by Changing Management Practices: The System of Rice Intensification in Madagascar. In Agroecological Innovations. Increasing Food Security with Participatory Development; Uphoff, N., Ed.; Earthscan: London, UK, 2002.

20. Woodgate, G.; Guzman, S. Transformative Agroecology: Foundations in Agricultural Practice, Agrarian Social Thought, and Sociological Theory. In Agroecology: A Transdisciplinary, Participatory and Action-Oriented Approach; CRC Press: Boca Raton, FL, USA, 2015.

21. Francis, C.G.; Lieblein, G.; Gliessman, S.; Breland, T.A.; Creamer, N.; Harwood, R.; Salomonsson, L.; Helenius, J.; Rickerl, D.; Salvador, R.; et al. Agroecology: The ecology of food systems. J. Sustain. Agric. 2003, 22, 99-118. [CrossRef]

22. Pretty, J.; Ward, H. Social Capital and the Environment. World Dev. 2001, 29, 209-227. [CrossRef]

23. Gliessman, S. Agroecology: Growing the roots of resistance. Agroecol. Sustain. Food Syst. 2013, 37, $19-31$.

24. Laszlo, E. The Inner Limits of Mankind: Heretical Reflections on Today's Values, Culture and Politics; One World: London, UK, 1989.

25. Boulding, K.E. Three Faces of Power; Sage Publications International Educational and Professional Publisher: London, UK, 1990.

26. Karlberg, M. The Power of Discourse and the Discourse of Power: Pursuing Peace through Discourse Intervention. Int. J. Peace Stud. 2005, 10, 1-25.

27. Escobar, A. Worlds and Knowledges Otherwise: The Latin American Modernity/Coloniality Research Program. Cult. Stud. 2007, 21, 197-210. [CrossRef]

28. Olsson, P.; Folke, C.; Berkes, F. Adaptive comanagement for building resilience in social-ecological systems. Environ. Manag. 2004, 34, 75-90. [CrossRef] [PubMed]

29. Francis, D. People, Peace, and Power: Conflict Transformation in Action; Pluto Press: London, UK, 2002.

30. Lederach, J.P. The Little Book of Conflict Transformation: Clear Articulation of the Guiding Principles by a Pioneer in the Field; Simon and Schuster: New York, NY, USA, 2015.

31. MacGinty, R. Where is the Local? Critical Localism and Peacebuilding. Third World Q. 2015, 36, 840-856. [CrossRef]

32. Richmond, O.P. Failed Statebuilding versus peace formation. Coop. Confl. 2011, 48, 378-400. [CrossRef] 
33. Bandura, A. Exercise of human agency through collective efficacy. Curr. Dir. Psychol. Sci. 2000, 9, 75-78. [CrossRef]

34. Holt-Giménez, E.; Shattuck, A. Food crises, food regimes and food movements: Rumblings of reform or tides of transformation? J. Peasant Stud. 2011, 38, 109-144. [CrossRef] [PubMed]

35. Lotz-Sisitka, H.; Wals, A.; Kronlid, D.; McGarry, D. Transformative, transgressive social learning: Rethinking higher education pedagogy in times of systemic global dysfunction. Curr. Opin. Environ. Sustain. 2015, 16, 73-80. [CrossRef]

36. Stirling, A. Emancipating Transformations: From Controlling 'the Transition' to Culturing Plural Radical Progress; STEPS Working Paper 64; STEPS Centre: Brighton, UK, 2014.

37. Gordon, L.R. What Fanon Said: A Philosophical Introduction to His Life and Thought. Book Discussion. 2015. Available online: http:/ / www.c-span.org/video/?325752-1/lewis-gordon-fanon-said (accessed on 22 July 2016).

38. Alexander, J. The Unsettled Land. State-Making and the Politics of Land in Zimbabwe 1893-2003; James Currey: Oxford, UK, 2006.

39. Stocking, M.A. Relationship of agricultural history and settlement to severe soil erosion in Rhodesia. Zambezia 1978, 6, 129-145.

40. Scoones, I.; Cousins, B. A participatory model of agricultural research and extension: The case of vleis, trees and grazing schemes in the dry south of Zimbabwe. Zambezia 1989, 16, 45-65.

41. Grant, P.M. Fertility of dambo soils and the related response of dambo soils to fertilisers and manure. In Dambo farming in Zimbabwe; Owen, R., Verbeek, K., Jackson, J., Steenhuls, T., Eds.; University of Zimbabwe Publications: Harare, Zimbabwe, 1995.

42. Wilson, K.B. 'Water Used to be Scattered in the Landscape': Local Understandings of Soil Erosion and Land Use Planning in Southern Zimbabwe. Environ. Hist. 1995, 1, 281-296. [CrossRef]

43. Murisa, T. Arrested Development: An Analysis of Zimbabwe's Post-Independence Social Policy Regimes. In Beyond the Crisis: Zimbabwe's Prospects for Transformation; Murisa, T., Chikweche, T., Eds.; Weaver Press: Harare, Zimbabwe, 2015.

44. Wall, P.C. Conservation Agriculture in Eastern and Southern Africa. In Conservation Agriculture: Global Prospects and Challenges; Jat, R.A., Sahrawat, K.L., Kassam, A.H., Eds.; CABI: Wallingford, UK; Boston, MA, USA, 2013.

45. Naome, R.; Rajah, D.; Jerie, S. Challenges in Implementing an Integrated Environmental Management Approach in Zimbabwe. J. Emerg.Trends Econ.Manag.Sci. 2012, 3, 408-414.

46. Moore, D. Suffering for Territory: Race, Place, and Power in Zimbabwe; Duke University Press: Durham, NC, USA, 2005.

47. Scoones, I. Command Agriculture and the Politics of Subsidies. Zimbabweland Blog. 25 September 2017. Available online: https: / zimbabweland.wordpress.com/ (accessed on 25 September 2017).

48. Department for Foreign Affairs and Trade. Country Information Report; Australian Government, April 2016. Available online: https:/ / dfat.gov.au/about-us/publications / Documents / country-information-reportzimbabwe.pdf (accessed on 22 July 2018).

49. ZHRC. Statement on Reported food Aid Cases. Presented by Zimbabwe Human Rights Commission at a Press Conference in September 2016. 2016. Available online: http:/ / www.zhrc.org.zw /index.php/ (accessed on 15 July 2017).

50. FCO. Zimbabwe-Human Rights Priority Country Status Report: January to June 2016; Updated February 2017; Foreign and Commonwealth Office. Available online: https://www.gov.uk/government/publications/ (accessed on 15 July 2017).

51. Connell, R.W. The Social Organization of Masculinity. In The Masculinities Reader, 2nd ed.; Stephen, M., Barrett, F.J., Eds.; Polity Press: Cambridge, UK, 2005.

52. Azar, E. The Management of Protracted Social Conflict: Theory and Cases; Dartmouth: Aldershot, UK, 1990.

53. Ghimire, K.B.; Pimbert, M.P. Social change and conservation: An overview of issues and concepts. In Social Change and Conservation: Environmental Politics and Impacts of National Parks and Protected Areas; Brüggemann, J., Ghimire, K.B., Pimbert, M.P., Eds.; Earthscan: London, UK, 1997.

54. Pimbert, M.P.; Pretty, J.N. Parks, people and professionals: Putting 'participation' into protected area management. Soc. Chang. Conserv. 1997, 16, 297-330.

55. Bernard, P.S. Ecological Implications of Water Spirit Beliefs in Southern Africa: The Need to Protect Knowledge, Nature, and Resource Rights. USDA For. Serv. Proc. 2003, RMRS-P-27, 148-153. 
56. Gonese, C.; Tuvafurem, R.; Mudzingwa, N. Developing Centres of Excellence on Endogenous Development. In Ancient Roots, New Shoots; Haverkort, B., Ed.; Zed Books: London, UK, 2002.

57. Tarusarira, J. African Religion, Climate Change, and Knowledge Systems. Ecum. Rev. 2017, 69, 398-410. [CrossRef]

58. Drinkwater, M. The State and Agrarian Change in Zimbabwe's Communal Areas; Palgrave Macmillan: New York, NY, USA, 1991.

59. Scoones, I. Landscapes, fields and Soils: Understanding the History of Soil Fertility Management in Southern Zimbabwe. J. South. Afr. Stud. 1997, 23, 619-620. [CrossRef]

60. Catholic Commission for Justice, Peace in Zimbabwe, \& Legal Resources Foundation (Zimbabwe). Breaking the Silence, Building True Peace: A Report on the Disturbances in Matabeleland and the Midlands, 1980 to 1988; Catholic Commission for Justice and Peace in Zimbabwe: Harare, Zimbabwe, 1997.

61. Richards, P. Agriculture as a performance. In Farmer First: Farmer Innovation and Agricultural Research; Chambers, R., Pacey, A., Thrupp, L., Eds.; Intermediate Technology: London, UK, 1989.

62. McAllister, G.E. Cultivating Social-Ecological Relationships at the Margins: Agroecology as a Tool for Everyday Peace Formation in Fragile Environments. Ph.D. Thesis, Coventry University, Coventry, UK, 2018.

63. Bourdieu, P. Pascalian Meditations; Stanford University Press: Chicago, IL, USA, 2000.

64. Primary data source: Dema Farmer Interview-DMA/FI/M/DBV/013. 23 June 2017.

65. Primary data source: Dema Elder Interview DMA/ACC/M/019. 28 June 2017.

66. Primary data source: Farmer Interview-MHT/FI/M/MC/014. 28 June 2017.

67. Primary data source: Traditional Leader Interview-CHK/CS-TL/M/KC. 29 November 2016.

68. Primary data source: Headman Interview-CASH/HM/M/SC. 26 October 2016.

69. Primary data source: Ward Councillor Interview-SHIN/WC/M/LM. 26 October 2016.

70. Primary data source: Farmer Interview-MHT/FI/M/MGT/05. 9 March 2017.

71. Primary data source: Agritex Extension Officer Interview-CHK/AEW/M/MS. 12 July 17.

72. Folke, C.; Carpenter, S.R.; Walker, B.; Scheffer, M.; Chapin, T.; Rockström, J. Resilience thinking: Integrating resilience, adaptability and transformability. Ecol. Soc. 2010, 15, 20. [CrossRef]

73. Tarusarira, J.; Manyena, B. Reconciliation in Zimbabwe: Building Resilient Communities or Unsafe Conditions? J. Confl. Transform. Secur. 2016, 5, 53-74.

74. Gunderson, L.; Light, S.S. Adaptive management and adaptive governance in the everglades ecosystem Farmer interview-MHT/FI/M/MGT/05 (09.03.17). Policy Sci. 2006, 39, 323-334. [CrossRef]

75. Maseko, P.; Scoones, I.; Wilson, K. Farmer-based research and extension. ILEIA Newsl. 1988, 4, 4.

76. Blaikie, P.; Cannon, T.; Davis, I.; Wisner, B. At Risk: Natural Hazards, People's Vulnerability and Disasters; Routledge: Abingdon, UK, 2003.

77. No wealth ranking exercise was undertaken, instead being gauged through observation and interview responses.

78. Bayat, A. Life as Politics. How Ordinary People Change the Middle East; Amsterdam University Press: Amsterdam, The Netherlands, 2010.

79. Burton, J. (Ed.) Conflict: Human Needs Theory; Conflict Series; Macmillan: London, UK, 1990; Volume 2.

(C) 2019 by the authors. Licensee MDPI, Basel, Switzerland. This article is an open access article distributed under the terms and conditions of the Creative Commons Attribution (CC BY) license (http://creativecommons.org/licenses/by/4.0/). 